\title{
C. C. Martindale (1879-1963), the History of Religions, and the Theological Imagination of David Jones (1895-1974)
}

\author{
Anna Svendsen \\ Department of English, Franciscan University of Steubenville, \\ Steubenville, $\mathrm{OH}, \mathrm{USA}$ \\ asvendsen@franciscan.edu
}

\begin{abstract}
Although the work of his Jesuit contemporaries Ronald Knox and Martin D'Arcy is perhaps better known today, C. C. [Cyril Charlie] Martindale's (1879-1963) thinking about "the relationship between paganism and Christianity" in the early twentiethcentury theological debates surrounding the field of "History of Religions" would have a profound effect on the unique intersection of theological thinking and artistic form in the work of the British Catholic poet and painter David Jones (1895-1974). Jones's reading of Martindale's short story collection The Goddess of Ghosts (1915) in 1919 would help to resolve a "religious crisis" Jones experienced in his exposure to the arguments of the skeptical scholar of "History of Religions," James Frazer. Martindale's presentation of his ideas in a literary form not only provided Jones with a hermeneutic (derived from the church fathers) for thinking about the relationship between paganism and Christianity, but also suggested an artistic model for exploring theological ideas with literary language.
\end{abstract}

\section{Keywords}

Jesuits-history-twentieth century - comparative religion - literary form-historytwentieth century - religion and literature - sacrifice - Christian theology - Eucharist - ressourcement (Catholic theology) 


\section{Introduction}

In his recent monograph, Poetry and Theology in the Modernist Period (2017), Anthony Domestico identifies the poet and painter David Jones (1895-1974) as one of several important Anglophone modernist artists in the early-to-mid-twentieth century (also including T. S. Eliot, 1888-1965, and W. H. Auden, 1907-73) who sought "to reclaim [. . . theological ideas-as a direct object of literary representation."1 For these artists, Domestico insists, "to write modern poetry was to consider such questions" as the relationship between eternity and history and so "to enter contemporary theological debate." In other words, their creative work was a vehicle for teasing out the implications of careful reading and discussion of theological texts they did elsewhere; it was also part of a dynamic, ongoing conversation, and "a vibrant, provisional method of knowing the world." ${ }^{3}$

The poetry and painting of Jones weaves together myriad themes (from Welsh mythology to shipbuilding to the First World War), but one constant of his work was his thinking about the theology of the eternal sacrifice (self-offering) of Christ on the cross and its relationship to the Eucharist. ${ }^{4}$ Jones was particularly interested in the relationship between the Mass and time, and constantly meditated on the Mass's ability to touch all moments of history through the dynamic of "re-presentation" (anamnesis). ${ }^{5}$ Scholars have focused on Jones's reading of the French Jesuit Maurice de la Taille (1872-1933) in his understanding of the theology of the Mass, ${ }^{6}$ but none have yet investigated his work in light of another Jesuit whom he encountered before de la Taille, and whose literary imagery arguably laid the ground for Jones's reception of de la Taille's theology. This other Jesuit was the English convert and Oxford classicist Cyril Charlie [C. C.] Martindale (1879-1963).

1 Anthony Domestico, Poetry and Theology in the Modernist Period (Baltimore, MD: Johns Hopkins University Press, 2017), 5 .

2 Domestico, Poetry and Theology, 4.

3 Domestico, Poetry and Theology, 9.

4 As David Jones (and Martindale, whose work will be addressed below) saw a synergy between the "Jesus of history" and the "Christ of faith," this essay accepts their framework for the purpose of analyzing the role of Christology in their work. Both the names "Jesus Christ" and "Christ" used throughout the essay therefore refer to this irreducible mystery as they understood it.

5 Jones had frequent recourse to the work of Dom Gregory Dix's discussion of the term anamnesis. See Dix, The Shape of the Liturgy (Westminster, UK: Dacre Press, 1945), 161.

6 Jones heard summaries of de la Taille's thought before reading his work in translation. De la Taille's major arguments are summarized in Maurice de la Taille, The Mystery of Faith and Human Opinion Contrasted and Defined, trans. J. B. Schimpf (London: Sheed and Ward, 1930). 
Martindale's 1915 short story collection, The Goddess of Ghosts, was what Jones called a "formative" influence in his own thinking about the relationship between paganism and Christianity, ${ }^{7}$ a topic that was itself an important theological debate at the heart of early twentieth-century Catholic theology vis $\grave{a}$ vis the newly emergent field of history of religions (sometimes also called comparative religion). Scholars of the history of religions frequently attempted to frame the person of Jesus Christ (both as a secular historical figure and as an object of faith) as merely one token of a sacrificial type found in pre-Christian mythology and religion. Believing Christians, on the other hand, contended that the figure of Jesus Christ (being equally God and man according to Christian faith) was radically unique, and his death and resurrection constituted the summit of all sacrifices in history. Martindale's Goddess of Ghosts-a work of fiction-was able to pierce to the roots of the theological issues at stake in this debate, neither rejecting the legitimate scholarly motivations of the history of religions nor compromising the traditional understanding of the figure of Jesus Christ as both God and man.

The "vibrant, provisional method" of Jones's own unusual artistic style arguably takes profound inspiration from a religious "crisis" generated by his reading in the history of religions that was "resolved" for him by the theologically saturated stories of Martindale. ${ }^{8}$ Not only the theological content of Martindale's meditation, but also the mode of its communication in a literary form would provide Jones with a formal key for his own thinking about theology in and through literary language as Domestico describes. Critics have long noted, for instance, the structure of Jones's works, especially his longest poem, The Anathemata, as marked by "spatial centers" 9 in tension with a sequential or episodic narrative; the particular language and thinking of Martindale's short stories sheds important light on Jones's association of a "spatial center" with the theology of the Mass that he saw as integral to the poem.

To understand the particular importance of Martindale's language and imagery — and therefore the importance it had for Jones—it is necessary to contextualize Martindale's work in some detail. In this essay, therefore, I will focus primarily on Martindale's work, and follow this discussion with some key principles that gesture towards a fuller investigation of his influence on Jones.

7 See Thomas Dilworth, David Jones: Engraver, Soldier, Painter, Poet (London: Jonathan Cape, 2017), 63 .

8 Dilworth, David Jones, 63.

9 Thomas Goldpaugh, "Mapping the Labyrinth: The Ur-Anathemata of David Jones," Renascence 51, no. 1 (1999): 253-80, here 262. 


\section{Martindale, the History of Religions, and the Church Fathers, $1905^{-15}$}

\section{The C.T.S. Lectures (1905-11)}

As John W. O'Malley (1927-) writes in his brief history of the Jesuits, "one of the most striking features of the intellectual culture of the nineteenth century" was its "introduction of historical methods into virtually all disciplines." ${ }^{10}$ The nineteenth- and early twentieth-century modernist controversy in the Catholic Church wound inextricably around the question of how to receive these "historical methods" as they related to the claims of Christian faith, ${ }^{11}$ and O'Malley notes that "the Jesuits [of the early twentieth century] [...] resisted the application of these methods to sacred subjects," to show their support of Pope Pius X's (1835-1914) condemnation of theological modernism (c.1905-10). O'Malley indicates that, therefore, a serious engagement with "historical methods" in relation to "sacred subjects" was taken up in earnest only later by Jesuit scholars such as Émile Mersch (1890-1940), and Henri de Lubac (1896-1991). ${ }^{12}$ The latter would become one of the most significant models of a return to the spiritual and historical "source" (ressourcement) of Catholic theology by means of a profound reacquaintance with the writings of second-to-fourth-century church fathers and their historical context.

Martindale was not a theological modernist, but from the very outset of his ministry in the early 19oos, he began the labor of engaging with nineteenthcentury "historical methods" of scholarship—-particularly as they were applied to the "sacred subject" of Christian theology and its relationship to other religions. Owing no doubt to his brilliant Classics career at Oxford (c.1901-5), as well as to his reception of the prestigious Ellerton Theological Essay Prize on Comparative Religion in $1907,{ }^{13}$ Martindale edited a series of pamphlets for the Catholic Truth Society that later became known as "The C.T.S. Lectures in 'History of Religions," published between 1905 and 1911. The project had an apologetic inspiration in that it responded to the challenges made by contemporary scholars in this relatively new field of study to many traditional claims of Christian faith.

10 John W. O'Malley, The Jesuits: A History from Ignatius to the Present (Lanham, MD: Rowman and Littlefield, 2014), 121.

For a fuller treatment of this subject, see Jeffrey Morrow's chapter, "Things New and Old: Loisy's Place in the Controversy over Modernism," in Morrow, Alfred Loisy and Modern Biblical Studies (Washington, DC: Catholic University of America Press, 2018), 11-30.

13 See Philip Caraman, C. C. Martindale: A Biography (London: Longmans, 1967), 86-9o; 101. 
The field of history of religions (or comparative religion) claimed an unbiased and historical investigation of the figure of Christ by placing him and the claims of the Christian tradition without any special designation alongside other central figures of religion and history. That is, they considered Christ without faith in his divinity and salvific character, and without deference to the church's authority to interpret the accounts of his life and works. Although the roots of skeptical investigation of the Judeo-Christian scriptures are much older than the work of the nineteenth-century French scholar Ernest Renan (1823-92), Renan's multi-volume Histoire des origines du christianisme, including its controversial first volume, Vie de Jésus (1863), most clearly embodies the school of criticism with which Martindale would engage in his scholarly work. Renan's method, in keeping with the emphasis on the "historical methods" of the nineteenth century, relied not only on Semitic philology but also on the significant expansion of archaeological excavation that appeared in the mid-nineteenth century. ${ }^{14}$ Renan was meticulous about citation: he relied on close reading of primary religious texts and historical accounts, and footnoted them carefully. He was a renowned teacher and inspired the work of many biblical critics in the next generation, among them the British anthropologist James Frazer (1854-1941), the French Catholic biblical critic Alfred Loisy (1857-1940), and the French archaeologist Saloman Reinach (1858-1932), all three of whom Martindale addresses directly in his essays and presentations in this period. ${ }^{15}$

As Robert Priest attests, what was convincing to the public about Renan's work was its "unashamedly accessible" style that used an "engaging narrative rather than extensive technical dissertations" to communicate his findings. ${ }^{16}$ In this vein, Renan and others of his school made a point of drawing on somewhat randomly chosen historical examples for the purpose of comparison, even though the unsystematic nature of the selection of these examples-especially in the case of Frazer-would ultimately open them to criticism. Renan compared the figure of Jesus Christ to the society-changing historical figures of Socrates (c.470-399 BCE) and Napoleon Bonaparte (1769-1821); Reinach

14 See Robert Daniel Priest's treatment of the composition history of the Vie de Jésus in The Gospel According to Renan: Reading, Writing and Religion in Nineteenth-Century France (Oxford: Oxford University Press, 2015), 69-108.

15 See C. C. Martindale, "Catholics and the Comparative History of Religions," The Tablet, 25 September 1909, 497-500.

16 Priest, Renan, 3. John Vickery also attests that this was true of Frazer's style. See John Vickery, The Literary Impact of The Golden Bough (Princeton: Princeton University Press, 1973), 1; 107. 
placed the practices of Christian "Communion and Theophagy" beside the "savage creed" of totemism. ${ }^{17}$

In the second edition of his magisterial The Golden Bough: A Study of Magic and Religion (1900), James Frazer made the even bolder assertion that it was only by "accident" that "the character of a divine revelation" was attributed to the "mainly $[\ldots]$ ethical mission" of Jesus Christ. ${ }^{18}$ His execution at the hands of the Roman empire simply recalled "the old, old story of the dying and risen god" (of pre-Christian mythology) and therefore appealed to the hearts of the Gentiles familiar with it in figures such as Adonis, Attis, and Osiris, etc. Frazer claimed that therefore "the devout Christian will doubtless discern types and forerunners of the coming Saviour" in the many examples of the "dying god" in pre-Christian mythology and nature worship, whereas "the sceptic [...] with equal confidence, will reduce Jesus of Nazareth to the level of a multitude of other victims of a barbarous superstition."19 Frazer saw himself as serving "truth" by showing Christianity to be merely a stage in the evolutionary enlightenment of humanity, which began with the "primitive" superstitions of "magic," graduated to the practice of "religion" (including Judaism and Christianity), but only as a stage on the way to the eventual and highest liberation of the human mind in "science." ${ }^{20}$ Frazer's imaginative extrapolation here of Charles Darwin's (1809-82) theory of the evolution of biological life-forms is unmistakable. ${ }^{21}$

Not only Martindale's intuitive grasp of the Latin language but also his own personal interest and feeling towards the pre-Christian nature religion of ancient Rome equipped him to engage with the burgeoning domain of study represented by Frazer and others-and to expose its own unacknowledged biases and methodological flaws. ${ }^{22}$ Martindale's edited series on the history of religions consisted of five volumes of written "lectures," each of which made an overview of the history, beliefs, and practices of a different non-Christian or non-Catholic religion. The series included topics as diverse and broad as

17 Ernest Renan, The Life of Jesus, trans. Charles Wilbour (London: Trübner, 1864), 18-19; Saloman Reinach, Cults, Myths, Religions, trans. Elizabeth Frost (Oxford: David Nutt, 1912), x. James Frazer, The Golden Bough: A Study of Magic and Religion, 2nd ed., vol. 3 (London: Macmillan, 1900), 197-98.

19 Golden Bough, 2nd ed., 3:198.

20 See especially the chapter "Magic and Religion," in James Frazer, The Magic Art and the Evolution of Kings, vol. 1, The Golden Bough: A Study in Magic and Religion, 3 rd ed. (London: Macmillan, 1906), 220-43.

21 See Robert Ackerman's discussion of the relationship between Darwin and late-nineteenthcentury social sciences in J. G. Frazer: His Life and Work (Cambridge: Cambridge University Press, 1987), 77.

See Caraman, Martindale, 89 . 
Mithraism and the religion of early Rome (both titles of lectures by Martindale himself) to the religion of China and the religion of the Avesta as a way of reflecting the breadth of material typically included in the works of Frazer and others. ${ }^{23}$ Martindale's concluding essay, "The Cults and Christianity," in the fifth and final volume of the series laid out his own comparative method for interpreting "the religious facts collected in the preceding lectures." ${ }^{24} \mathrm{He}$ claimed that the "collection of facts" practiced by Frazer and others is "legitimate" as long as it does not "presuppose a mechanical law of religious evolution," that is, does not arbitrarily apply Darwin's theory of the evolution of life-forms to the history of religions, as Martindale insisted the work of Frazer and others did. ${ }^{25}$

Although his project was apologetic in nature, Martindale was one of the first scholars to anticipate the modern consensus about the work of Frazer, who is now criticized not for his expression of unbelief but, ironically, for his unscientific use of historical methods. Robert Ackerman begins his 1987 biography of Frazer with the assertion that, from hindsight, "Frazer is an embarrassment" to the modern academic establishment. Not only did he rely on "crude and ethnocentric reports of other cultures," but his apparently historically derived "ethnographic evidence" is in fact "culled from here and there and everywhere, to illustrate propositions which he had arrived at in advance by $a$ priori reasoning." Scholars today therefore do not read Frazer's work for any intrinsic merit, but rather to understand how it influenced others of his time. ${ }^{26}$

Martindale's response to Frazer in his own day did not simply find flaws in the misapplication of the evolutionary hypothesis to the study of religion (Frazer's "proposition arrived at in advance by a priori reasoning") but took the opportunity to turn the thesis of Frazer and others on its head. With Martindale's own examination of what he called the "religious facts" both of Christianity and pre-Christian nature religions - which he lays out in his own essay in a very meticulous pattern similar to that of Frazer and Reinach, etc.he comes to the conclusion that "the great feature of Christianity, when it is put alongside of or among other faiths, is Christ. It is quite idle to seek in the shadowy, semi-mythical heroes of other religions anything at all like Him."27 Martindale was therefore confident that any truly disinterested historical study of the "facts" of Christianity vis à vis the history and theology of other religions

23 Lectures on the History of Religions, ed. C. C. Martindale, 5 vols. (London: Catholic Truth Society, 1905-11).

24 C. C. Martindale, "The Cults and Christianity," Lectures on the History of Religions, 5:1-72, here 1.

25 Martindale, "Cults and Christianity."

26 Ackerman, Frazer, 1.

27 Martindale, "Cults and Christianity," 38-39. 
would reveal the uniqueness of the person of Jesus Christ, both from a secular historical perspective and from the perspective of Christian faith.

Furthermore, Martindale took the opportunity to search into the roots of the theological issues at hand in a fascinating anticipation of the twentiethcentury theological ressourcement. He asked the question: What indeed, from the perspective of Catholic theology and the history of the church, is the relationship between these clearly similar story arcs of "the dying god" from pre-Christian nature religion and the mystery of Jesus Christ still knowable today in the Catholic faith? Instead of appealing to the idea of the figures in pre-Christian religion as coincidental "types and forerunners" of Christ-as Frazer anticipated the Christian response to his arguments would be-Martindale (with the help of the church fathers) penetrated to the deeper understanding of the sacrifice of Christ on the cross as an act taking place in both historical time and timeless eternity, and therefore mysteriously present in its effects from the beginning of historical time. His focus was not, therefore, on the similarity of superficial forms between pre-Christian figures and the story of Christ, but on the deeper mystery of God's permeating presence and action in relation to his creation.

Martindale ultimately relies on a visual metaphor to communicate this patristic insight about the relationship between time and eternity and Christ's relationship to creation. Towards the middle of his essay, Martindale writes: "What we may look for, therefore, in the consciousness of the Fathers, is a profound conviction that Christianity has not been lacking from the beginning of the world." 28 Throughout this section, he appeals to a range of early church fathers including Augustine (354-430), Justin Martyr (100-165), Gregory Nazianzen (329-90), Tertullian (155-240) and others. ${ }^{29} \mathrm{He}$ ultimately turns to a paraphrase of Revelation 13:8:

The Lamb was slain from the beginning of the world. Christ's magnetism radiates backwards as well as forwards, through the ages; Calvary is the centre point of time, as once it was believed the centre of the earth [sic];

28 Martindale, "Cults and Christianity," 48.

29 Martindale, "Cults and Christianity," 40 ff. Martindale in particular mentions Gregory Nazianzen's discussion of the "gradual revelation of God in history," from the Theological Orations (quoted in Martindale, "Cults and Christianity," 47-48n5). He must also have in mind the common image of the cross as present in the very fabric of nature and time, as in the discussion of Irenaeus of Lyon's Demonstration. See Irenæus, Demonstration of Apostolic Preaching, trans. J. Armitage Robinson (New York: Macmillan, 1920), 101. See also Joseph Ratzinger's discussion of this topic in his The Spirit of the Liturgy, trans. John Saward (San Francisco: Ignatius Press, 2000), 177-84. 
in all that has been and shall be, Christus cogitatur. The key to universal history is Christ. ${ }^{30}$

Martindale uses the strikingly visual and spatial image of a "centre" as a metaphor for the mysterious relationship between the continuously moving plot points of historical time (each with its sense of the passing "present") and the unchanging "eternal present" in which God dwells. By means of the mystery of the incarnation, in which the eternal, infinite God "took flesh" in a particular human body and particular time and place, the self-offering of Christ in his death on the cross in $c .33$ is not only a temporal but also an "eternal" offering. This eternal moment is not somehow abstracted from historical time or coming only after the end of historical time but is continually present to all points of historical time at once, the way the center of a wheel touches all its spokes at once.

Martindale's image of the "centre" illustrates the relationship between the death and resurrection of Christ and the "death and resurrection" stories of different pre-Christian figures of the "dying god" in a unique way. Although the rituals and myths of pre-Christian religion come before the historical advent of Jesus Christ's incarnation and life on earth, they genuinely intuit something of his mystery, because he is continually present to all moments of historical time from eternity. In this paradigm, therefore, the particular image of "death and resurrection" in the myths of pre-Christian sacrificial figures is not simply a coincidence of forms that appears in hindsight: it is a vision of Christ's eternal sacrifice in his death and resurrection in a veiled or partial form.

Although it is unlikely that C. S. Lewis (1898-1963) read Martindale's essay on "The Cults and Christianity," Lewis gives a particularly pertinent illustration of the same idea in his 1944 lecture, "Is Theology Poetry?" Here, Lewis asserts that the story of Jesus Christ is not one mere instance of myth among many, but a "myth made fact." 31 In articulating "the differences between Pagan Christs (Balder, Osiris, etc.), and the Christ himself" Lewis insists that

it is not the difference between falsehood and truth. It is the difference between a real event on the one hand and dim dreams or premonitions of that same event on the other. It is like watching something come gradually into focus; first it hangs in the clouds of myth and ritual, vast and

$30 \quad$ Martindale, "Cults and Christianity," 48.

31 C. S. Lewis, "Is Theology Poetry?," in They Asked for a Paper (London: G. Bles, 1962), 150-62, here 157 . 
vague, then it condenses, grows hard and in a sense small, as a historical event in first century Palestine. ${ }^{32}$

Lewis implies here, like Martindale, that in a pre-Christian imagination there is some genuine (if partial) intuition of the reality of Christ by means of his dual nature. Neither Lewis nor Martindale suggest that the practice and belief of pre-Christian religion bears no substantial difference from ChristianityMartindale clarifies this point in his discussion of Tertullian ${ }^{33}$-but one must acknowledge a mysterious relationship between the two that cannot be reduced to mere coincidence of forms.

\section{The Goddess of Ghosts (1915)}

In keeping with the recourse of Jesuit thinkers to the imagination in both prayer and evangelization, Martindale expressed the central thesis of his work on the comparative method of the history of religions in both a formal scholarly essay such as the "The Cults and Christianity," and in the artistic medium of the short story. His work therefore represents an early twentieth-century instance of making "theological ideas" into what Domestico (quoted above) calls "a direct object of literary representation."

The medium of literary language, furthermore, spoke to the literary quality of Frazer's (and others') appeal to the general public. Frazer's work was most successful because of its rhetorical force and power of suggestion and not, as time and subsequent investigation have shown, because of the power of his scientific argumentation and exposition. So also, in turn, lay the success of Martindale - at least in the case of his influence on the young poet, painter and Wwi veteran David Jones.

Martindale began writing stories expressing his intuition about the relationship between Christianity and pre-Christian religion as early as his Oxford years, c.1904-5. His short story, "The Goddess of Ghosts," published around this time in the Jesuit periodical The Month was his first foray into this genre and would provide the name for his collection of similarly themed short stories that he would publish in $1915 .{ }^{34}$ His biographer, Philip Caraman (1911-98), describes "The Goddess of Ghosts" as emanating from Martindale's personal feeling for the "Latin world," and in particular for the nature religion of

32 Lewis, "Is Theology Poetry?," 157.

33 Martindale, "Cults and Christianity," 48nı.

34 Some other of the stories written at this time and published in The Month and The British Review would be included in In God's Nursery (1913) and The Waters of Twilight (1914). See Caraman, Martindale, 96n2; 117 . 
pre-Christian early Rome as well as the "mystic, almost Christian" poetry of Virgil. ${ }^{35}$ The stories of the 1915 collection, The Goddess of Ghosts, feature the intersection of pre-Christian nature religion and Christianity in a number of unusual ways. They pay particular attention to the question of "life" and the common reverence in pre-Christian religion and Christianity for the entanglement of human life with the life of nature. Martindale sets his stories either in classical antiquity in which pre-Christian characters, weary of their philosophy and failing religious enthusiasm, encounter the new Christian religion; or in modern times (i.e. the early twentieth century) in which Christian characters (frequently jaded Englishmen) see Christianity afresh through some kind of encounter with the pre-Christian past.

In the last story of The Goddess of Ghosts, titled "The Faun," Martindale illustrates most clearly the thesis he puts forward in "The Cults and Christianity" about the mysterious intuition of Christ and his sacrifice in the pre-Christian reverence for the divine origin of human life and nature. Martindale extends this thesis to show its implications for the Eucharist, the sacramental "re-presentation" of the eternal sacrifice of Christ in the Mass. Set in c.19oo, it stars a young English widower named Basil Croft who finds himself with his young daughter, Ursula, living in an Italian villa surrounded by countryside. Both Basil and Ursula, who are English Catholics, have visions in their garden of a "faun" as from classical mythology, an anthropomorphic emanation of the landscape who seems to mirror their own ages and temperaments. Basil, because he "loved to philosophize," concludes that "the Faun was, as it were, the expression, or the formal manifestation of the life that was ultimate in all that countryside" and that he "united in himself humanity and the wild life of plant and herd and wind and sun." Basil is troubled because, as a Catholic, he thinks he should not be able to see figures of the religion of "pagandom," which he assumed was entirely "divorced" from the church. ${ }^{36}$

On the day Ursula takes her first Communion, however, in the local Church of Santa Maria all'Acqua Cadente, "built above the yet older grotto of the Nymphs," a friar comes to their villa and walks with them in their garden. As they tell him about seeing the Faun, the friar tells Ursula (with a side glance at Genesis) $)^{37}$ that before she had received the Eucharist, "you didn't know as well as you do now who it is that walks in gardens when the sun sets." ${ }^{38}$ The

35 Caraman, Martindale, 89-90.

36 Martindale, Goddess of Ghosts, 211-12.

37 See Genesis 3:8: "they heard the voice of the LORD God walking in the garden in the cool of the day" (King James version).

38 Martindale, Goddess of Ghosts, 215 . 
implication is that Christ veiled in the Eucharist is in fact the one who "walks in gardens" (the same God of Genesis) and hence mysteriously animates the divinely originated spirit of creation represented by the figure of the Faun. The friar then addresses the elements of nature directly as he sings the "Canticle of Creatures" of St. Francis of Assisi (1181-226), as well as the "Canticle of the Three Children" from Daniel 3 (the latter a prayer traditionally said after the reception of the Eucharist), which invokes the various elements of the natural world to "bless the Lord."39

Martindale's story reuses some important word-choices from "The Cults and Christianity" that develop his thinking about the sacrifice of Christ on the cross as the "centre point of time." When Basil muses on the joy of Ursula and the friar in nature that comes from their reception of the Eucharist, he describes them as "at that Centre [...] which is everywhere." ${ }^{40}$ The repetition of the visually charged word "Centre" here serves to highlight the association between the cross and the Eucharist as one with the source of Christ's creative action that made the world from the "centre point of time," that is, from eternity. It is the same source that also redeems the world through the self-offering of Christ's eternal sacrifice in his death and resurrection, in turn re-presented in the Eucharist.

The image of the "centre" draws on a long tradition of thinking about the relationship between God, time, and eternity in the Christian imagination from the church fathers to Boethius $\left(c .477^{-524}\right)$ to Dante Alighieri's (1265-1321) Paradiso, and in the twentieth century to Eliot's Four Quartets. It also touches on one of the most vexed questions of theology in a modern context, which Eunsoo Kim summarizes as the "problem of the relationship between divine transcendence and divine immanence." ${ }^{41}$ Martindale's language and imagery do not attempt to close the conversation on this immense and complex topic; on the contrary, they are meant to open the mind to its mystery in a way that symbolic and literary language uniquely has the power to do. In his general preface, Martindale identifies the theme of the collection as what he called "the mystery of life" that "remains a mystery even without the capital L." ${ }^{22}$ For him the mystery of "life" is not only a scholarly but also a personal and prayerful question, and in his literary work he attempts to make sense of it in a way

39 See for instance the section titled "Thanksgiving after Mass," in David Jones's missal: Fernand Cabrol, ed., The Roman Missal in Latin and English (London: B. Herder, 1931), $62 a$.

40 Martindale, Goddess of Ghosts, 218.

41 Eunsoo Kim, Time, Eternity, and the Trinity: A Trinitarian Analogical Understanding of Time and Eternity (Eugene, OR: Wipf and Stock, 2010), 3.

42 Martindale, Goddess of Ghosts, vi. 
that attends to it primarily as experienced in the encounter with God, the sacraments, nature, and the study of history. Literary language in this case allows Martindale to present the mysterious totality of this contemplative insight.

The discussion of theological ideas by focusing on experience and mystery (typical of the presentation of literary language), and strongly animated by engagement with the church fathers, would characterize many endeavors of theological thinking in the twentieth century. Martindale's engagement with these ideas on a scholarly as well as literary level speaks very much to Anthony Domestico's claims about the interpenetration of literature and theology in a twentieth-century context. This is the same dynamic in which the poet and painter David Jones himself would participate.

\section{The Fruit of Labors: C. C. Martindale's Patristic Hermeneutic in the Work of David Jones}

Martindale was not nearly as concerned about sparring with belligerent academics as he was about reaching the audience he called "the man in the street," who had been more affected by the work of authors like Frazer and others than past generations of lay people. ${ }^{43}$ In this concern-at least in the case of the young layman, artist, and WWI veteran, Jones - the imagery of Martindale's short stories more than his academic arguments per se would have the effect he desired.

Jones's biographer, Thomas Dilworth, makes only a small mention of the impact Martindale's Goddess of Ghosts had on the young Jones:

In 1919, Jones's reading of Jessie Weston's From Ritual to Romance and especially Frazer's The Golden Bough precipitated a religious crisis by revealing similarities between Christianity and paganism. Then, the same year, he read The Goddess of Ghosts (1915), a collection of stories by the classicist C.C. Martindale SJ, which resolved his doubts by disclosing the spiritual intimations of paganism as validated by Christianity and what Jones would call the 'Vegetation Rites of the Redeemer'. Martindale's book was a major influence-Jones said, 'formative. 44

43 See Martindale's paper from the Catholic Truth Society Conference in Manchester, 1909, reprinted as "Catholics and the Comparative History of Religions," The Tablet, 25 September 1909, 497-500.

44 Dilworth, David Jones, 63. Note: Dilworth says Jessie Weston's (1850-1928) book was part of this immediate postwar moment, and Blissett similarly recounts that Jones told him he had 
It is unclear exactly how Jones came across the book, but it is likely his small circle of Catholic friends at the time introduced it to him. They would also introduce him to Fr. John O'Connor (1870-1952) - by happenstance the model for G. K. Chesterton's (1874-1936) Fr. Brown stories-the priest who would confirm him in the Catholic Church in $1921 .{ }^{45}$

It is also unclear precisely which stories or what parts of them had the impact that Jones described to Dilworth, but two stories in the collection - the title story, "The Goddess of Ghosts," and the final story, "The Faun" (described above) - contain the most powerful imaginative responses to the nineteenth-century skepticism Frazer represents. Jones in any case would have been fairly familiar with Martindale's overall thinking about the relationship between Christianity and pre-Christian religion because he had the opportunity to speak extensively with Martindale in person about that particular subject during a visit to Campion Hall, Oxford, in 1922. ${ }^{46}$

Jones's only published reference to the influence of Martindale is buried in a long, sundry list in the preface to his second long poem, The Anathemata, where he mentions the names of fifty people who shaped the thinking underlying the work. The name C. C. Martindale appears towards the middle, between Géza Róheim (1891-1953) and Friedrich von Hügel (1852-1925). Also on the list, towards the beginning, are James Frazer and Jessie Weston. First on the list is Maurice de la Taille, referring to the French Jesuit theologian from whom Jones most explicitly claimed his understanding of the eternal sacrifice of Christ and the Mass. ${ }^{47}$ Jones was deeply impressed with de la Taille's discussion of the Mass in relation to the universal human dynamic of "signs." He was, furthermore, impressed by de la Taille's language about the sacrifice of Christ, specifically his emphasis on the "oblation" (self-offering) of Christ in the Last Supper as being the same eternal event as his "immolation" in his death on Calvary. De la Taille, in turn, emphasized this eternal act as the same event

encountered both Frazer and Weston before he read The Waste Land, but Weston's book was not in fact published until 1920 and evidence from Jones's letters indicates that he did not read Weston until the late 1920 s and well after reading Frazer. See William Blissett, The Long Conversation: A Memoir of David Jones (Oxford: Oxford University Press, 1981), 96; and David Jones, Dai Greatcoat: A Self-portrait of David Jones in His Letters, ed. René Hague (London: Faber, 1981), 46.

45 See Dilworth, David Jones, 63.

46 Dilworth, David Jones, 77: "At meals there [in Campion Hall] Jones discussed the relationship of paganism to Christianity with Cyril Martindale."

47 David Jones, Preface to The Anathemata: Fragments of an Attempted Writing (London: Faber, 1952), 36-37. 
sacramentally re-presented in the Catholic Mass. ${ }^{48}$ As early as 1919, however, Jones would have encountered Martindale's particular patristically derived image of the sacrifice of Christ (re-presented sacramentally in the Eucharist) as an eternally present "center" of history. It is possible to conjecture, therefore, that this "formative" shaping of Jones's imagination laid the ground for his later reception of de la Taille's more abstract theological argumentation and, in turn, Jones' own "direct representation of theological ideas" in his art.

Although all of Jones's poetic works (and a large portion of his visual ones) engage with the theology of the Eucharist, The Anathemata most clearly suggests a debt to Martindale's image of the sacrifice of Christ on the cross (and in the Eucharist) as a "Centre [...] that is everywhere." The style of The Anathemata has been compared to the modernist innovations of Eliot, Ezra Pound (1885-1972), and James Joyce (1882-1941) in its fragmentation. In this nearly 285-page work, Jones patches together unexpected rhythms and rhymes from bits of songs, Scripture verses, and other works. In line with other modernists, his range of allusions includes: Roman and Celtic pre-Christian nature deities, medieval historical and mythical figures (the legends of Arthur were a central preoccupation), glimpses of the Catholic Mass and the figure of Christ, and many other figures, events, and words in the British "res" (what Jones also calls "the very things of which one is oneself made.") ${ }^{49}$ In his preface, Jones claims that the work is a meandering series of "fragments [...] which, by a kind of free-association are apt to stir in my mind at any time and as often as not 'in the time of the Mass." 50 He insists ultimately that "what I have written has no plan, or at least is not planned. If it has a shape, it is chiefly that it returns to its beginning." ${ }^{51}$ This commentary seems to point to a multifarious subject matter and generally linear, episodic structure, but which "returns" in a generally cyclical motion.

Thomas Dilworth and Thomas Goldpaugh, however, have read The Anathemata as having a "spatial," and specifically "circular" dimension to its

48 See Dilworth, David Jones, 74. Jones read de la Taille's The Mystery of Faith and Human Opinion Contrasted and Defined in English translation after he converted in the 1920s. It should be noted that de la Taille's work is considered an important precursor to the theological ressourcement of the twentieth century and the Liturgical Movement. He was known and commented upon by some of the most notable twentieth-century theologians, including de Lubac and Karl Rahner (1904-84); he was also a colleague of Réginald Marie Garrigou-Lagrange (1877-1964). See the "Introduction" of Michon Matthiessen in Sacrifice as Gift: Eucharist, Grace and Contemplative Prayer in Maurice de la Taille (Washington, DC: Catholic University of America Press, 2013), 1-30.

49 Jones, Preface to Anathemata, 10.

50 Jones, Preface to Anathemata, 31.

$5^{1} \quad$ Jones, Preface to Anathemata, 33. 


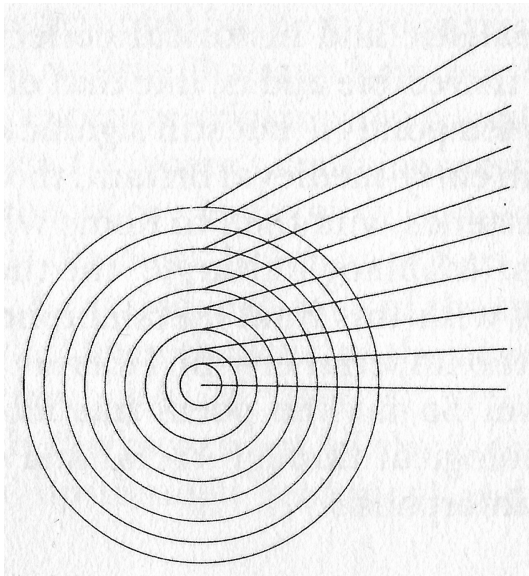

elevation of the Eucharist (49-244) questions dating paschal events $(94-185)$ ship's arrival at Phaleron (96-182) Elen's calling her wares (125-68) warning about winter (125-68) catalogue of churches (127-6I) Elen's mason-lover ( $130-60$ ) education by sea captains (135-59) the Syro-Phoenician's stories (155-8) redemption and the Eucharist (156-7)

FIGURE 1 Circular structure of The Anathemata

TOM Dilworth's THE SHAPE OF MEANING IN THE POETRY OF DAVID JoNES (TORONTO: UNIVERSity OF TORONTO PRESS, 1988), WITH PERMisSion OF THE AUTHOR

structure in addition to the episodic, linear dimension that Jones himself identifies. ${ }^{52}$ More recent studies such as W. David Soud's Divine Cartographies (2016) and Anthony Domestico's Poetry and Theology in the Modernist Period (2017) reinforce this reading. ${ }^{53}$ Dilworth, in his The Shape of Meaning in the Poetry of David Jones, provides a diagram (reproduced here as Fig. 1) to explain what he understands to be the presence of Jones's "recessive" or concentric thematic circles that move progressively "inward" to the midpoint of the sequential narrative. ${ }^{54}$

At this midpoint (or "center") of Jones's sequential narrative-page 157 of the total of 244-Dilworth observes that Jones provides a description of the eternal sacrifice of Christ (what Dilworth labels in his diagram "redemption and the Eucharist"). ${ }^{55}$ In this passage, Jones mixes images and language from the sixth-century Latin hymn for the cross, Vexilla Regis, the nursery rhyme "Sing a Song of Sixpence," Geoffrey Chaucer's (c.1340-400) Prologue to The Canterbury Tales, and T. S. Eliot's The Waste Land, to create an image of the

$5^{2}$ See Thomas Dilworth's chapter on the "form" of The Anathemata for his full analysis of this image in The Shape of Meaning in the Poetry of David Jones (Toronto: University of Toronto Press, 1988), 152-74. See also Goldpaugh, "Mapping the Labyrinth," 255.

See W. David Soud, Divine Cartographies: God, History and Poiesis in W. B. Yeats, David Jones, and T. S. Eliot (Oxford: Oxford University Press, 2016), 130; and Domestico, Poetry and Theology, 67 .

54 Taken from Dilworth, Shape of Meaning, 168. Reproduced with kind permission of Thomas Dilworth.

55 Dilworth, Shape of Meaning, 168-69. 
eternal sacrifice of Christ (both in the crucifixion and the Eucharist) as the "tree of life": the source and redemption of the life of creation. ${ }^{56}$

In Dilworth's estimation, this passage is not only the sequential midpoint (or "center") of Jones's ambling linear meditation but also is shown to be the thematic center of the work. As the linear narrative makes thematic "parentheses" or "circles" around this central passage, by the same token the passage permeates the whole and touches all points of the linear narrative at once, as from another dimension. As Dilworth points out, the poem's beginning and ending points are "simultaneous" in that they narrate the celebration of a single Mass. Theologically speaking, the same cosmic action, re-presented in the Mass, appears also in the central passage of the work. The action of the eternal sacrifice of Christ in the Mass therefore envelops all other activity in the poem, from the earliest geological formations of the world to the present time. Dilworth's reading is confirmed by some of Jones's own later commentary on the composition of The Anathemata and the plan of its many drafts. ${ }^{57}$ Dilworth's interpretation has also been confirmed and expanded upon by Thomas Goldpaugh, who discusses the presence of "spatial centers" in many of Jones's works and in his general composition process. ${ }^{58}$ If Dilworth and Goldpaugh are correct, The Anathemata's central image of Christ in his "redemption and the Eucharist" is therefore Martindale's "Centre [...] that is everywhere" in the work's linear narrative.

It would be imprudent to suggest that Martindale would have been the only thinker behind this cosmic vision of time and eternity intimated by this structure. Jones identifies the central image of The Anathemata as "the Tree of the Cross as the axial beam around which all things move" taking this particular phrase from the "monastic motto" of the Carthusians, Stat crux dum volvitur orbis (the cross stands still while the world revolves around it). ${ }^{59}$ Martindale's patristic image of the cross of Christ as a "center" is therefore one that works in tandem with other images that Jones likely first encountered in Martindale's work.

The hermeneutic provided by Martindale's imagery and thought sheds light not only on the structure of The Anathemata but also on Jones's curious juxtaposition of pre-Christian religion and Christianity in the work. This essay does not allow detailed explication of this subject, but I will simply point to a few

56 Jones, Anathemata, 157.

57 Dilworth, Shape of Meaning, 169-70.

$5^{8}$ Goldpaugh, "Mapping the Labyrinth," 255-59.

59 David Jones, "Wales and the Crown," in Epoch and Artist: Selected Writings by David Jones, ed. Harman Grisewood (London: Faber, 1959), 39. 
salient examples of Jones's curious juxtapositions. The work's first section, "Rite and Foretime," meditates largely on the pre-historical geological formations and religion of Britain and Europe. Jones describes the slow terraforming of the Ice Age (which ended in Europe c.12000 BCE) naming the figure of Cronos (the mythical Greek embodiment of time and the forces of destruction) as one who "reads the rubric, frangit per medium, when / he breaks his ice like morsels, for the therapy and fertility / of the landmasses." ${ }^{\prime 60}$ The precise, italicized Latin phrasing frangit per medium, is the Roman Missal's instruction to the Catholic priest at a particular moment in the Mass to "break [the Eucharistic host] down the middle" before he consumes it. ${ }^{61}$

Understanding the liturgical context of this allusion shows the reference here to have the deliberate shock of a metaphysical conceit. It is at the same time a technique of modernist bathos and might tempt one to recall the punning irreverence of James Joyce (an artist Jones deeply admired). With the lens of Martindale's patristic thinking, however, one can also see David Jones using literary language here to work through a complex theological idea. The figure of Cronos (named as such and revered in pre-Christian myth and religion) manifests a genuine intuition or "dim dream" about the presence of Christ himself at work in his creation from eternity-a creative action that is one with Christ's sacrificial offering and that is re-presented sacramentally in the Catholic Mass. In a real sense, therefore, the passage shows Jones thinking through the implications of this theological question: If the sacrifice of Christ is present to all moments of time (including the terra-forming of the Ice Age), then, by extension, is not the priest's breaking of the host at Mass-a literal re-presentation of this same eternal sacrifice-somehow present in the terra-forming of the Ice Age too?

A more explicit example of Jones's questioning theological mode appears in this section where he meditates on the thirty-thousand-year-old fertility goddess statue known today as the "Venus of Willendorf." ${ }^{2}$ Jones directly asks about it:

Then it is these abundant ubera, here, under the species of worked lime-rock, that gave suck to the lord?

60 Jones, Anathemata, 69 .

61 See Jones's note in Anathemata, 227n2.

62 Today housed in the Naturhistorisches Museum, Vienna, Austria. For images and more information about this artefact, see Kathleen Kuiper, "Venus of Willendorf," Encyclopedia Britannica, https:/www.britannica.com/topic/Venus-of-Willendorf (accessed April 22, 2021). 
they already venerate (what other could they?)

her we declare?

Who else?63

Folding in passages from the Gospels and the Hebrew Scriptures (Luke 11:27; Isaiah 66:11), Jones thinks through the implications of another pre-Christian intuition of the mystery of Christ. He asks: If pre-Christian religion intuits something true (if partial) about the mystery of Christ because of the proximity of his action upon his creation from eternity, is it not a true inkling of Christ's mother, the Virgin Mary, that the fashioner of the "Venus of Willendorf" venerated in his statue (itself an image of ideal motherhood)? In this case, as in many other passages in the work, Jones explicitly includes a question mark to indicate the open-endedness of this meditation. He is not finished thinking about it. As Domestico observes, Jones's poetic style represents a dynamic mode in which he thinks through the implications of his most pressing and serious theological questions while allowing them to remain a mystery. This literary mode, as well as the seed of many questions about "the relationship between paganism and Christianity," arguably found an inspiration in the stories of Martindale.

Reading Jones's The Anathemata in light of Martindale also opens up new possibilities for interpreting the structure and themes of his other works. As Goldpaugh has insisted, "all of Jones' works [...] are marked by spatial centers" that frequently persist alongside a "linear" or episodic narrative. ${ }^{64}$ Goldpaugh identifies this structure in Jones's poetic memoir of the First World War, In Parenthesis (1937), which-like The Anathemata-Jones had described in his published commentary as simply linear, detailing the trajectory of his memory from his first training in 1915 to the harrowing battle of Mametz Wood (part of the Somme Offensive) in July, 1916. ${ }^{65}$ As Goldpaugh observes, however, Jones places a mystical, monologic sequence (frequently referred to as "The Boast of Dai Greatcoat") about the universal role of soldiering in history in the center of his work as a key to the whole. ${ }^{66}$

At the climax of this sequence, and roughly in the "center" of the linear narrative of In Parenthesis (page 87 of the total of 183), appears a description of the sacrifice of Christ as a "living tree" in the midst of the wwi Wasteland. If read in light of Martindale's patristic hermeneutic, it is possible, as in The

\footnotetext{
63 Jones, Anathemata, 6o.

64 Goldpaugh, "Mapping the Labyrinth," 262.

65 David Jones, Preface to In Parenthesis (London: Faber, 1937), ix.

66 Goldpaugh, "Mapping the Labyrinth," 259.
} 
Anathemata, to read a vision of the sacrifice of Christ as permeating the whole of the story's linear timeline from its "centre point" in eternity. Furthermore, as in The Anathemata, so In Parenthesis contains unmistakable references to pre-Christian figures such as Frazer's "dying god," which mingle obliquely with the image of Christ on the cross. Critics have struggled to situate these references within In Parenthesis as a whole, but Martindale's patristic paradigm suggests a compelling interpretation that has not been possible before.

Martindale's patristic hermeneutic in turn arguably informs the intersection of Christian and pre-Christian subjects in Jones's visual works, which were produced contemporaneously with his written works. To point to a small example, Jones writes explicitly that the pre-Christian "Yggdrasil" (world tree) from the Hávamal of Norse mythology is meant to appear in the central tree of his understated crucifixion image, Vexilla Regis (1948), thereby implying a relationship of some kind with the cross of Christ. ${ }^{67}$ In light of Martindale's literary presentation of the mystery of the cross, one can read a visualization of the relationship between the creative action of Christ from eternity and what Lewis calls the "dim dream of that same event" in pre-Christian mythology and religion. This relationship appears in Jones's visual style as the recognition of multiple figures overlapping in a single "shape": the Yggdrasil of Norse mythology "is" the cross of Christ inasmuch as it genuinely intuits the creative action of Christ from eternity at work in creation.

The complex "shape" of Jones's literary and artistic investigation of theological ideas is a good example of the fruit that can emerge from religious "crisis" and the patient work of "resolution." Arguably generated by the encounter with the skeptical narrative of Frazer's The Golden Bough in tandem with the cosmic vision presented in Martindale's The Goddess of Ghosts, the adaptation of the image of Christ's eternal sacrifice as the "centre point of time" in the work of Jones reveals Jones's entrance into the "contemporary theological debate" on the question of Christ's unique status in history. Martindale had led the way, using both scholarship in "historical methods" and modern literary language to create a "vibrant, provisional method for knowing the world" of divine mysteries in a twentieth-century context.

67 See Jones, Dai Greatcoat, 152. A digital reproduction of Vexilla Regis is viewable on the Kettle's Yard Museum website: https://www.kettlesyard.co.uk/collection-item/vexilla-regis/ (accessed April 3, 2021). 